RADOVI

UDK 7.025:629.313:069(497.523Varaždin)

Zavod za znanstveni rad

Pregledni članak

HAZU Varaždin

Review

LJERKA ŠIMUNIĆ

Gradski muzej Varaždin

Primljeno: 15. 01. 2019.

ljerka.simunic@gmv.hr

Prihvaćeno: 03. 10. 2019.

DOI: $10.21857 / y 6 z o l b 87 g m$

TOMISLAV SIKINGER

Restauratorski odjel Ludbreg

Hrvatski restauratorski zavod u Zagrebu

tsikinger@h-r-z.hr

\title{
ŠARAGA IZ DVORCA OBITELJI LEITNER U JALKOVCU
}

Tekst je sastavljen od dva dijela: prvi analizira predmet $u$ muzejskoj zbirci Kulturno-povijesnog odjela GMV i daje pregled njegovih prvotnih vlasnika, članova varaždinske obitelji Leitner. Drugi dio opisuje opsežne i složene konzervatorsko-restauratorske radove koje provode stručnjaci Restauratorskog odjela Ludbreg HRZ-a u Zagrebu. 


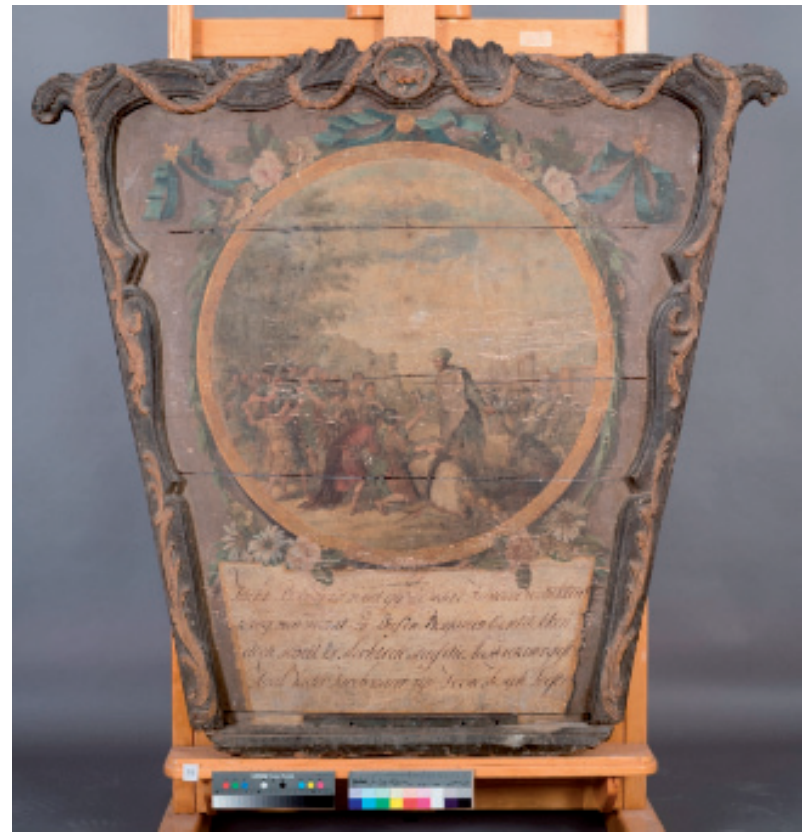

Slika 1. Šaraga u Restauratorskom centru u Ludbregu, HRZ u Zagrebu, 2015.

U Restauratorskom centru u Ludbregu HRZ-a u tijeku su konzervatorsko-restauratorski radovi na oslikanom drvenom predmetu tkz. šaragi koji se čuva u Zbirci namještaja, satova i zrcala Kulturno-povijesnog odjela Gradskog muzeja Varaždin. Ime šaraga ${ }^{1}$ je arhaizam u hrvatskom jeziku, ustvari germanizam², a označava drvenu ogradu na stražnjoj strani kola, izrađenu od drva, koja se prema potrebi, može maknuti. Zaprežna kola mogla su, uz stražnju imati pomičnu i prednju stranicu, pa je naziv za obje ogradice bio šaraglje. Sačuvani predmet u muzejskoj zbirci vjerojatno je stražnja stranica kočije ili reprezentativnih kola čiji ostali dijelovi nisu sačuvani. Šaraga ${ }^{3}$ ima oblik trapeza, sa širom stranicom usmjerenom prema gore, sastavljena je od spojenih dasaka unutar rezbarenog i pozlaćenog okvira. Sprijeda, unutar okvira nalazi se središnji medaljon sa zlatnim rubom ispunjen prikazom iz starozavjetne priče o Josipu, dok je donji prostor u obliku paralelograma ispunjen tekstom na flamanskom jeziku koji pojašnjava

1 https://www.scribd.com/doc/123120058/ARHAIZMI-ISTO\%C4\%8CNE-SLAVONIJE.

2 Njem. Schragen - šaraglje, stražnja stranica kola, stranica stražnjeg dijela kola ili stranica koša u kolima

3 Čuva se u Zbirci namještaja, zrcala i satova Kulturno-povijesnog odjela Gradskog muzeja Varaždin, inv. br. GMV 59333. 
oslikani prizor. Medaljon s pozlaćenim rubom okružen je rezbarenim vijencem od ruža i modrih vrpci. Crno obojeni okvir ukrašen je reljefno izvedenim listovima akantusa, pozlaćenim viticama i isprepletenim vijencem koji u središnjem gornjem dijelu uokviruje maleni medaljon s plastičnim prikazom krave. Predmet je ispupčen prema gledatelju. Straga, s gornje strane pričvršćena su dva velika metalna koluta kroz koji je provučen željezni lanac na kojem je predmet visio.

Nije moguće provesti preciznu analizu gradbeno-oblikovnog sklopa cjelovitog predmeta s obzirom da je sačuvan tek fragmentarni dio veće cjeline, kočije ili kola. Jedino je moguće prema stilskim značajkama sačuvanog fragmenta barem djelomično uspostaviti sliku mogućeg ustroja, te mjesto i vrijeme njegova nastanka uz prihvaćanje činjenice da će ostati mnogo otvorenih pitanja i nedoumica. Ostaje nepoznato ime majstora stolara, drvorezbara i polikromatora čija su znanja i vještine korišteni pri izradi ovog predmeta. Razlog tome je što su oni u 18. stoljeću najčešće bili smatrani majstorima ili obrtnicima bez izraženog autorstva, te su u potrazi za poslom često migrirali, mijenjajući boravišta, seleći se iz grada u grad, ovisno o narudžbama koje su dobivali. S obzirom na holandski tekst na šaragi, te razvijene poslovne veze članova obitelji Leitner koje su održavali u mnogim europskim zemljama pa i u Nizozemskoj, moguće je, da je prijevozno sredstvo ili samo njegov oslikani dio stigao u Leitnerovu dvorac u Jalkovcu iz nekog flandrijskog grada, možda čak Amsterdama. Prema stilskim karakteristikama možemo ga datirati u posljednju četvrt 18. stoljeća, između 1780-1790.

Predmet, veličine 136 × 119 cm, sastavljen je od nekoliko drvenih dijelova međusobno povezanih, rezbarenih, oslikanih temperom uz dodatak pozlate. Prije dolaska u Gradski muzej Varaždin bio je izložen u salonu dvorca Leitner među ostalim umjetninama o čemu svjedoči fotografija iz obiteljskog albuma. Album je pred desetak godina Muzeju poklonila gospođa Anina Leitner iz Amsterdama. Ana (Anina) Leitner kćer je Stjepana i sestra Alfreda Leitnera, posljednjih vlasnika poljoprivrednog dobra Jalkovec. Album ${ }^{4}$ je dragocjeno svjedočanstvo o izgledu dvorca i njezinog interijera snimljenih 1928. godine. Fotografije pojedinih salona prikazuju stilski inventar upotpunjen različitim umjetničkim djelima. Unutar neuglednih korica albuma nalazi se dvadeset i tri crno-bijele fotografije snimljene 1928. godine. Tri fotografije prikazuju dvorac izvana, sedamnaest su snimci različitih stambenih prostorija, dok su posljednje tri portreti vlasnika, Stjepana pl. Leitnera. Na fotografiji ${ }^{5}$ jednog od salona, na zidu, iznad ormara, nalazi se ovješena šaraga.

4 Zbirka fotografija i razglednica KPO-a GMV, inv. br. GMV 77666.

5 Inv. br. GMV 77666/4. 


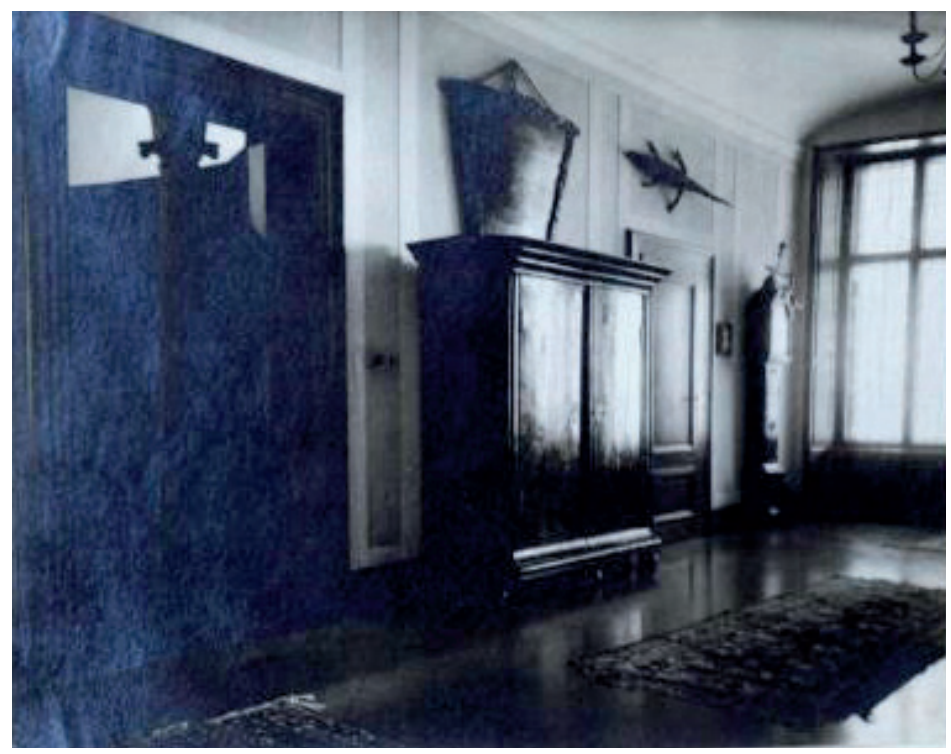

Slika 2. Fotografija šarage u salonu dvorca Leitner

Stjepan pl. Leitner kupio je početkom 20. stoljeća kuriju plemićke obitelji Josipović u Jalkovcu nedaleko Varaždina, koju je srušio i na njenom mjestu 1911. sagradio novi dvorac ${ }^{6}$ prema projektu njemačkog arhitekta Paula Schultza-Naumburga ${ }^{7}$. Schulze-Naumburg bio je osnivač i voditelj uglednog projektnog biroa, umjetničke i arhitektonske škole pod nazivom Saalecker Werkstätten Salleck bei Bad Kösen ${ }^{8}$. Fotografije s prikazom dvorca rastvorenog pročelja prema perivoju $s$ nizom prozora prvog i drugog kata i mansardnim krovom, te pojedinih interijera, snimljene su petnaestak godina nakon izgradnje, vjerojatno kad je završeno njezino kompletno uređenje i oblikovanje perivoja. Saloni opremljeni probranim stilskim pokućstvom i umjetninama, reprezentativno ovalno predvorje $s$ francuskim prozorima i ostakljenim oculusima, terasa s pletenom garniturom od šibe $s$ pogledom na drveće odaju eklektički ukus vlasnika.

Szabo, Gjuro, Kroz Hrvatsko Zagorje, Zagreb, 1939, str. 127.

7 Njemački arhitekt, slikar i publicist Paul Schulze često se javlja pod imenom: Paul Schultze-Naumburg (1869.-1949.).

8 Žig navedenog projektnog biroa nalazi se na jednom od sačuvanih listova projekta s prikazom južne fasade dvorca. 


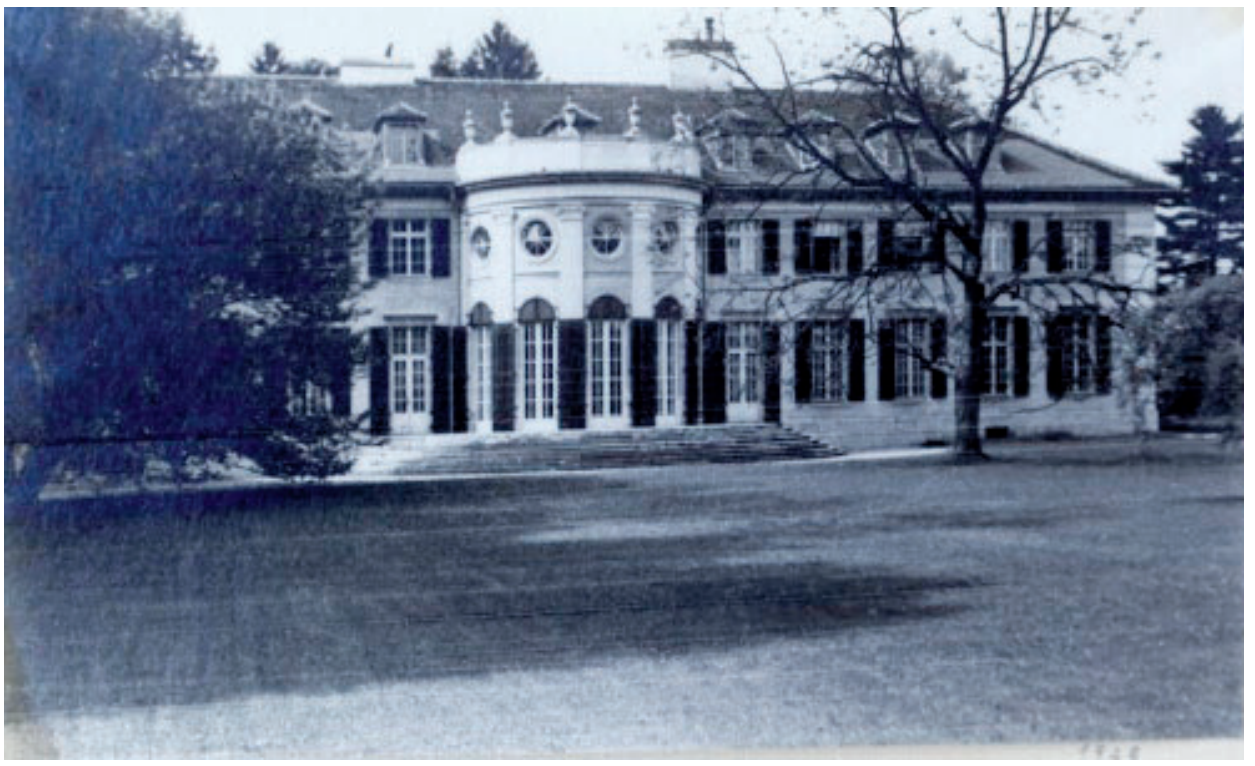

Slika 3. Pročelje dvorca Leitner, 1928., GMV 77666/14
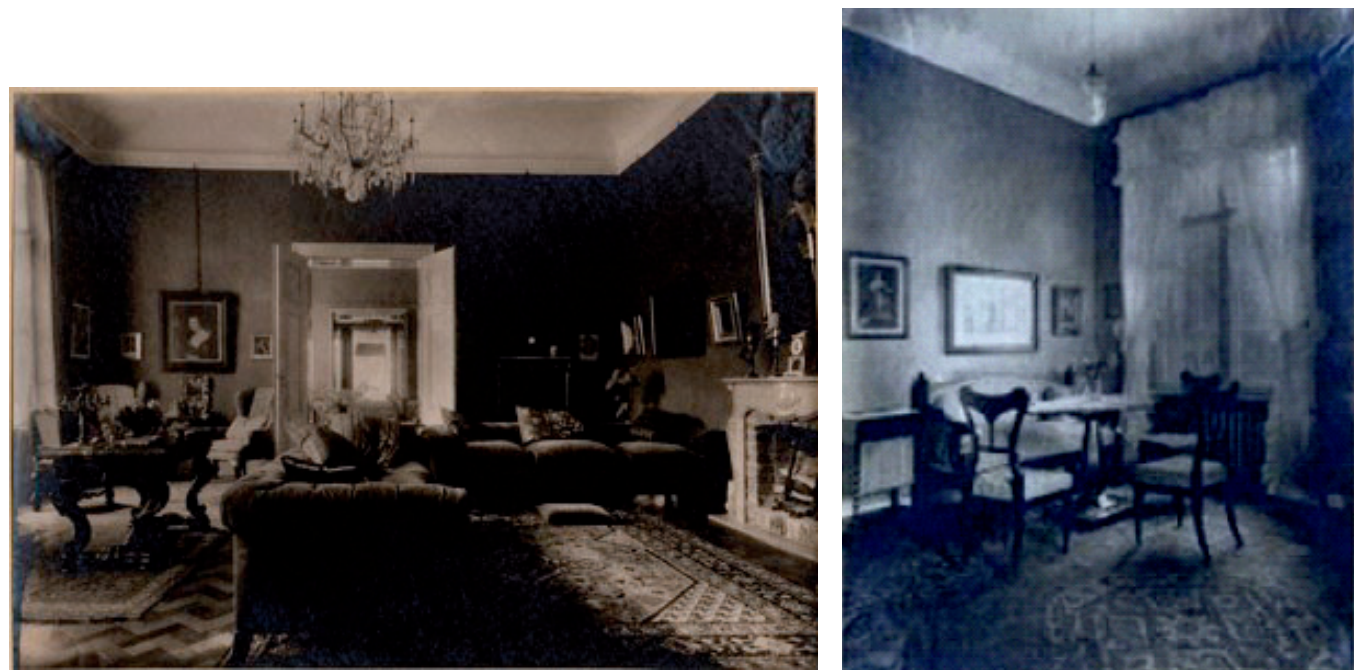

Slike 4. i 5. Saloni u dvorcu, GMV 77666/8,14 


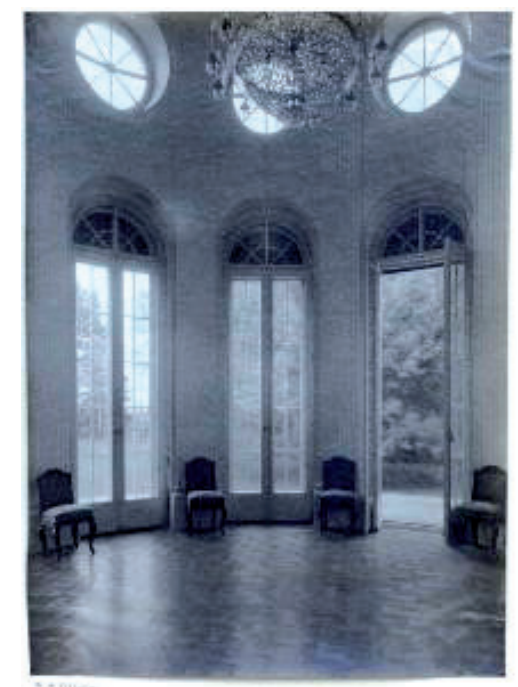

Slika 6. Predvorje dvorca Leitner, GMV 77666/7

Leitneri su židovska obitelj, čije se prezime spominje u Bavarskoj, već u 14. i 15. stoljeću, a u 18. stoljeću prisutno je u mnogim zemljama Europe i Novog svijeta, SAD-a i Kanadi. ${ }^{9}$ Prvi članovi te obitelji stigli su u Varaždin vjerojatno iz Graza, u prvoj polovici 19. stoljeća. ${ }^{10}$ Prvi Leitner zabilježen u varaždinskim arhivskim dokumentima je Samuel koji je 1830.u Varaždinu osnovao veletrgovinu vinom pod imenom „S. Leitner und Sohn“. Tijekom života zajedno sa sinovima stekao je zavidni imetak u gradu i njegovoj okolici. Njegov sin Albert, uspješan poduzetnik i promicatelj kulture, sagradio je na svom vinogradarskom posjedu na Varaždinbregu ljetnikovac ${ }^{11} \mathrm{~s}$ pozornicom i glazbenom dvoranom gdje su se održavali koncerti i kazališne priredbe, koji je ubrzo postao središte društvenog života Varaždinaca i brojnih gostiju iz Hrvatske i inozemstva. Suvremenici spominju profinjeno uređeni interijer, njegovan engleski perivoj s ružičnjakom, raznolik vrijedan inventar koji je uključivao veći broj različitih vrsta kočija, od onih namijenjenih za lov do najelegantnijih primjeraka za prijevoz ukućana i gostiju. ${ }^{12}$ Bili su imućni posjednici, uspješni gospodarstvenici koji su razvili odlične trgovačke veze po cijeloj Austrijskoj Carevini i inozemstvu, školovani glazbenici, pozna-

\footnotetext{
9 https://www.houseofnames.com/leitner-family (09.06. 2019.).

10 Prvog člana obitelji, Samuela (1797.-1872) nalazimo na popisu varaždinskih Židova 1825-26.

11 Vjekoslav Leitner kupio je 1907.posjed na Tremu koji se nalazio na Malom vrhu nedaleko Kneginca od varaždinske gradske općine.

12 Svoboda, B. Stare vinogradske kurije, Varaždin, 1967., str. 59.
} 
vatelji i ljubitelji umjetnosti, kao dobročinitelji aktivni članovi mnogih građanskih društva i udruga. Židovskog porijekla, Samuel Leitner doprinio je izgradnji varaždinske sinagoge. Jedan od njegovih sinova, Vjekoslav ${ }^{13}$ osnovao je sredinom 19. stoljeća tvrtku za trgovinu i posredovanje u trgovanju željeznom robom na veliko na cijelom području jugoistočne Europe. Godine 1910. car i kralj Franjo Josip I. dodijelio je njegovom sinu Stjepanu s obitelji plemićku titulu ugarskog plemstva s pridjevkom de Varaždinbrieg zbog zasluga na području gospodarstva i dobrotvorstva. ${ }^{14}$ Stjepan pl. Leitner bio je podupiratelj mnogih građanskih udruga među njima i Muzealnog društva zaslužnog za osnutak Gradskog muzeja Varaždin 1925. godine. Novoosnovanom Muzeju donirao je umjetnine za stalni postav. Zajedno sa sinom Alfredom ${ }^{15}$ poklanjao je vrijedne povijesne i umjetničke predmete sve do svoje smrti. Iste 1910. godine je sa ženom Marijom, rođenom Bonn prihvatio katoličku vjeru pokrštenjem u župnoj crkvi sv. Nikole u Varaždinu. ${ }^{16}$

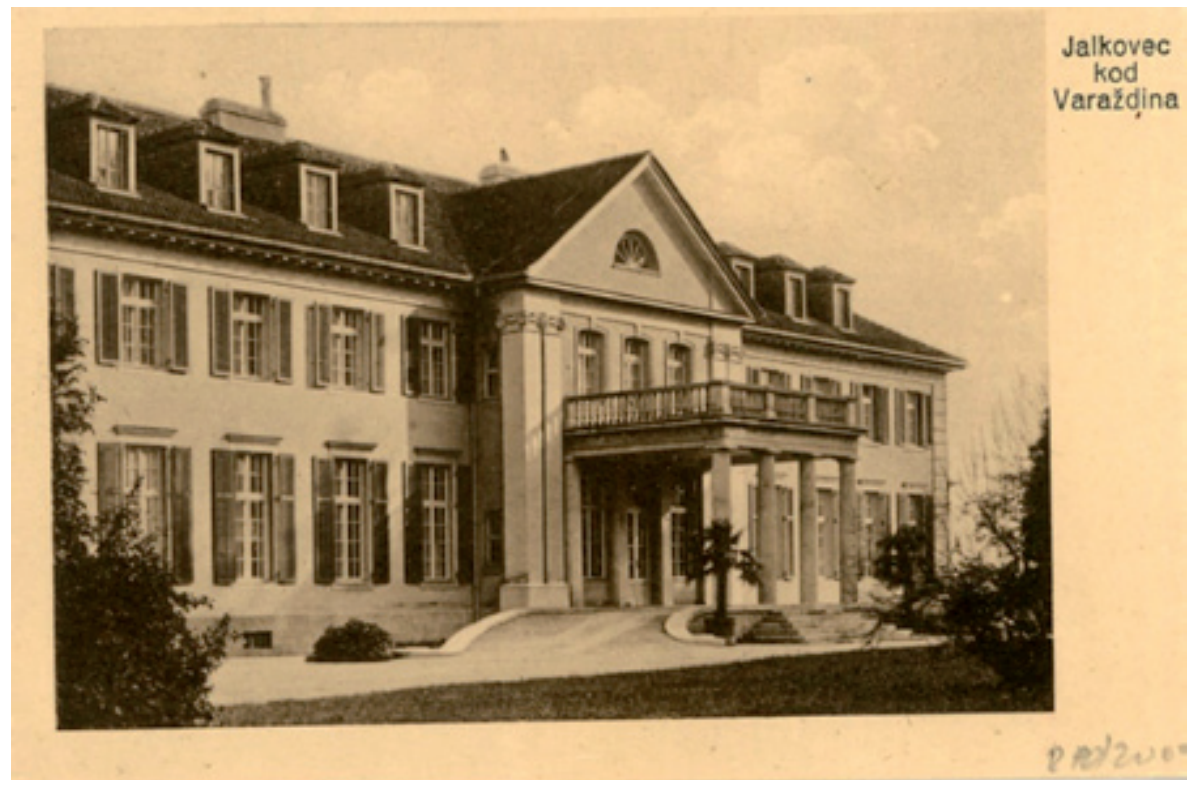

Slika 7. Razglednica s prikazom dvorca Leitner, oko 1915.

\footnotetext{
13. Lončarić, Magdalena, Židovska zajednica u Varaždinu, Varaždin, 2017, str. 186.

14 Grbovnica obitelji Leitner, Gradski muzej Varaždin, inv. br. GMV KPO 9127.

15 Alfred pl. Leitner (Varaždin, 1898.-1945.) bio je tajnik Muzealnog društva.

16 HR-DAV-2 1112, Obitelj Leitner-Puszt 1868-1955.
} 
S uspostavljanjem Nezavisne države Hrvatske Leitnerima je već u jesen 1941. zbog njihovog židovskog porijekla zaplijenjena imovina.

Dvorac u Jalkovcu pretvoren je u dom za ratnu siročad, a dio nepokretne i pokretne imovine predan je na korištenje različitim državnim i gradskim ustanovama. Odlukom Državne riznice za državnu imovinu Ministarstva seljačkog gospodarstva 10. rujna 1942 . cjelokupni imetak je podržavljen. ${ }^{17}$ Pokućstvo iz dvorca iste je godine preuzelo Njemačko mjesno zapovjedništvo. ${ }^{18}$ Pod točkom 8. potvrde o preuzimanju pokućstva upisane su slike, ali bez detaljnog opisa koji bi omogućio njihovu precizniju determinaciju. O oduzimanju imovine od travnja 1941. do proljeća 1945. godine svjedoči veći broj dokumenata, uglavnom odluka i potvrda o predaji, zapljeni i preuzimanju nekretnina s oranicama i livadama, automobila, ${ }^{19}$ poljoprivrednih alatki, pokućstva i umjetnina. ${ }^{20}$ Jedan od dokumenata o preuzimanju sedamdeset dvije umjetnine potpisao je Krešimir Filić u studenom 1944., ${ }^{21}$ a slijedeće 1945. preuzeto je i pohranjeno u Muzej još deset predmeta. ${ }^{22}$

\section{0.- JaRuGW stražnja stranica kold/.0d drva oeliknna se rezba= renim, dijelon poslabonim okvirom, Iifa eredini ploðe,koja je u obliku trapezs/sa girtaei stranloom gore/ nelast ae okrugli medajlon a prisorom is price。 Josipu.Ispod medaljons je kartuse sa holandejsicim tokstoz, koj1 se odnosi ne prizor.iledaljon ins ruti alikani aliki okvir, a oko nje v1jenso ovijeó 1 vrpce.slikarlja 1zvedens gustom teaperom u Ladin gotovo pasteinim tonoving.0kvir je po stranala 1 dolje ravnog izvanjakog ruba, prema unutarnjoj otrani 1zrezuakan. IIa gornjoj strand u eredini je okrugli nedaljon a relijefnom poslaćenom kravom,od kojega na obe strane v1jugaju ormaimentirene vrpce 1 po otranans se epujtaju atilinirani voj1 u Ameterdanu. Kamo 18 stolj.velirina 119 $136 \mathrm{o} / \mathrm{m}$.}

Slika 8. Detalj s popisa predmeta preuzetih iz dvorca Leitner u studenom 1944.

17 HR-DAVŽ - Leitner-1112, 2.2127.

18 Varaždinsko Gradsko poglavarstvo izdalo je potvrdu o preuzimanju pokućstva na dobru Jalkovec.

19 HR-DAVŽ - Leitner-1112, 06. 04. 1941. Stjepanu Leitneru je rekviriran automobil Mercedes Benz tip 230.

20 Dokumenti iz arhive Gradskog muzeja Varaždin.

21 Popis antiknih predmeta iz dvorca Jalkovec-Stjep. pl. Leitner prenesenih u županijsku zgradu studeni g. 1944. KF - iz arhive Gradskog muzeja Varaždin.

22 Arhiv GMV, 3. srpnja 1945.predmete je preuzeo privremeni upravitelj Gradskog muzeja Varaždin, ali dokument nije potpisan i ovjeren. 
Nakon Drugog svjetskog rata Židovi su u novoj socijalističkoj Jugoslaviji bili izjednačeni s ostalim stanovništvom što je uključivalo i nacionalizaciju njihove imovine. O preuzimanju i pohrani umjetnina iz dvorca Leitner u Jalkovcu i njihovom smještaju prvo u zgradi Okružnog N.O.O.-u Varaždinu ( županijska palača) ${ }^{23}$ i njihovom preseljenju u Gradski muzej Varaždin sačuvani su dokumenti iz 1945.; popisi br. 37. od 7. lipnja i od 3. srpnja, te potvrda br. 41. od 16. srpnja.

Umjetnine je za Muzej preuzeo prof. Krešimir Filić. ${ }^{24}$ Šaraga je s većim djelom umjetnina dopremljena u Muzej 03. srpnja 1945.

Do početka Drugog svjetskog rata Leitneri su prikupili znatnu kolekciju predmeta umjetničke i kulturološke vrijednosti kojima su opremili svoj dvorac u Jalkovcu, ljetnikovac na Varaždinbregu i kuće u Varaždinu. S obzirom da su trgovali na veliko, školovali se i održavali poslovne veze u različitim europskim gradovima, za pretpostaviti je da su za vrijeme svojih putovanja nabavljali umjetnička djela, glazbala, notni materijal i skupocjene predmete. Jedan dio obitelji Leitner živio je (i još uvijek živi) u Amsterdamu pa je moguće da je kočija ili oslikana stranica nabavljena u Nizozemskoj, a na što upućuje tekst na flamanskom jeziku. Svakako je riječ o raritetnom predmetu u hrvatskim muzejima. Nakon završenih konzervatorsko-restauratorskih radova biti će izložen u stalnom postavu Kulturno-povijesnog odjela Gradskog muzeja Varaždin u Starom gradu.

\section{Šaraga}

Nizozemska (Flandrija ?), oko 1780.- 1790.

hrastovo i jasenovo drvo, rezbareno, polikromirano, pozlaćeno

136 x 119 x 70 cm, inv. br. GMV 59333

Registrirano kulturno dobro Z - 3793

Detaljniju interpretaciju oslikanog prizora i teksta bilo je moguće provesti nakon izvedenog prvog dijela konzervatorsko-restauratorskog postupka s obzirom da je predmet bio u lošem stanju.

U središnjem medaljonu, unutar zlatnog okvira smještena je scena s grupom likova u prvom planu; slijeva, od strane gledatelja su Josipova braća dok je zdesna njegov upravitelj s peharom u ruci. Uokolo se prostire krajolik sa životinjama i ljudima. Prikazani je dio iz Povijesti Josipa i njegove braće $e^{25}$ koji se odnosi na

23 Zgrada Velike župe Zagorje u Varaždinu u vrijeme NDH.

24 Popis stvari dopremljenih sa podržavljenog dobra Leitner u Jalkovcu i pohranjenih u zgradi velike župe Zagorje u Varaždinu, arhiv GMV.

25 Stari zavjet, Knjiga postanka, Povijest Josipa i njegove braće (44:11). 
trenutak kad je otkriven (podmetnuti) srebrni pehar u vreći najmlađeg Josipovog brata Benjamina. Josipov upravitelj stoji s vrčem u desnoj ruci koji mu pruža jedan od stražara, drugi okiva lancima najmlađeg Jakovovog sina Benjamina odjevenog u žutu odjeću kod kojeg je pronađen pehar. Središnji lik odjeven u zelenu halju je Juda.

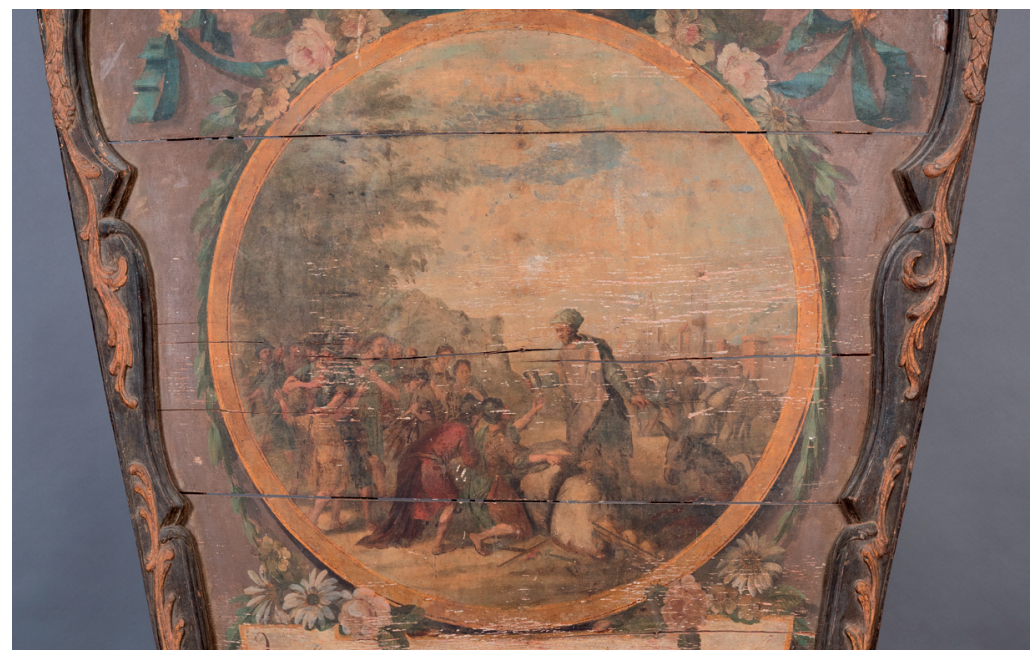

Slika 9. oslikani prizor iz Starog zavjeta, detalj

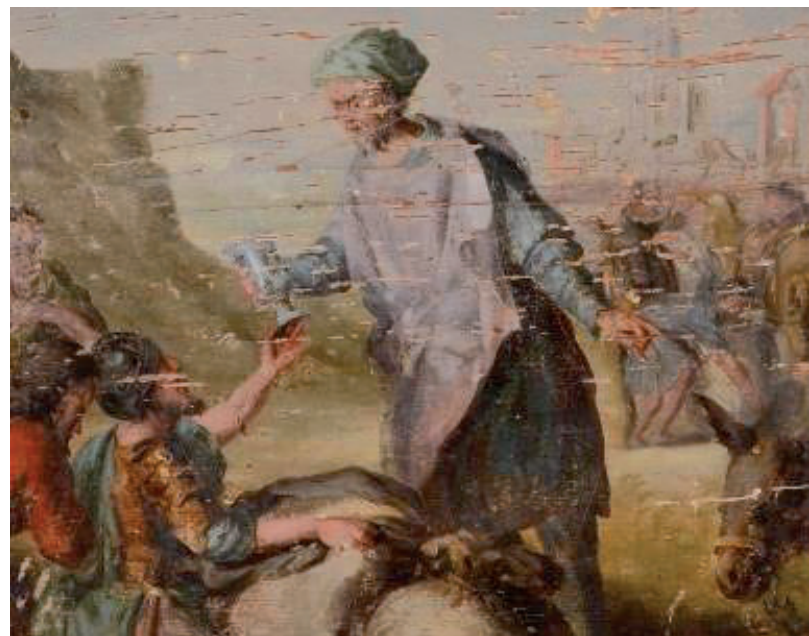

Slika 10. Detalj s prikazom upravitelja s peharom

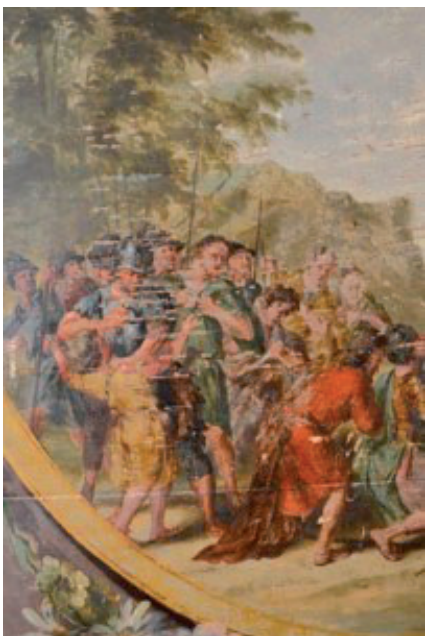

Slika 11. Detalj s Josipovom braćom 


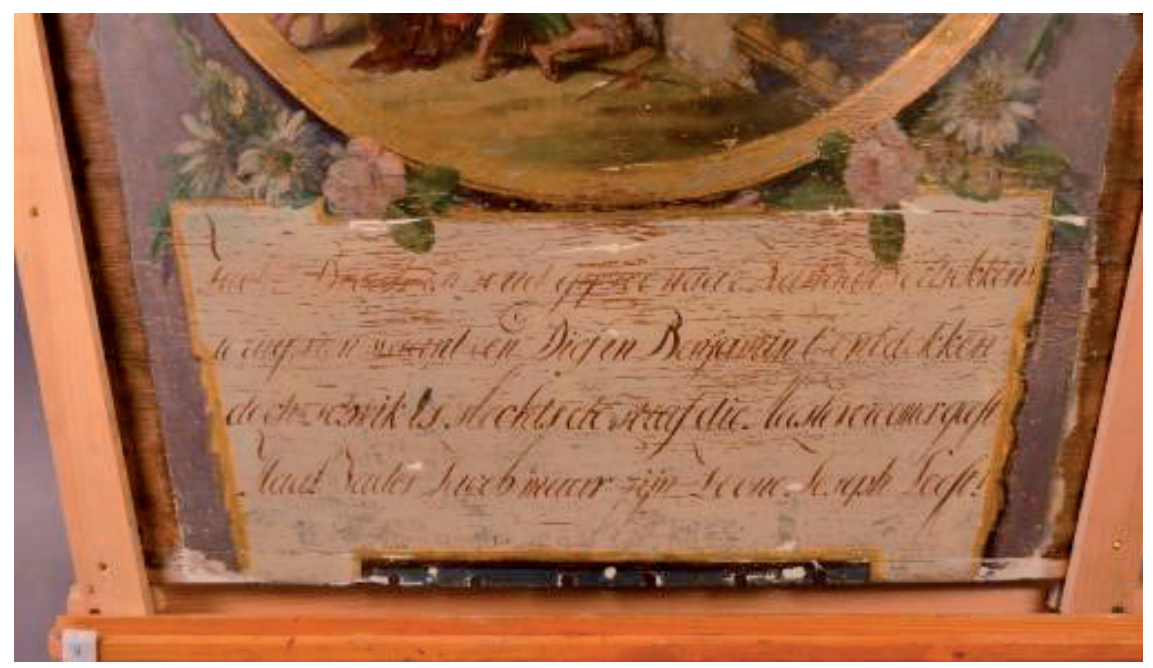

Slika 12. Zapis ispod oslikanog prizora

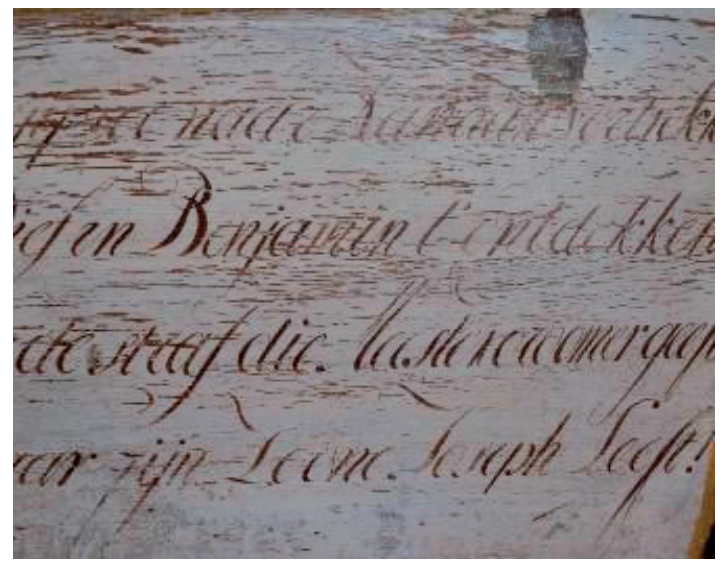

Slika 13. Detalj teksta sa šarage

Oslikani prizor pojašnjava holandski tekst koji spominje Josipa, „kradljivca“ Benjamina i njihovog oca Jakova. U slobodnom prijevodu dio čitkog teksta glasi: „Smijte se braćo biste li sada krenula za Kanaan? Onda, ljudi smatraju da su lopova u Benjaminu otkrila ipak strah je najgora kazna.......Dovedite oca Jacoba jer je njegov sin Joseph živ! „,

26 Zahvaljujem Andrei i Fransu Blanshardu na prijevodu s nizozemskog jezika. 
Starozavjetna priča o Josipu kojeg su ljubomorna braća prodala i koji je u egipatskom ropstvu stekao povjerenja faraona, ugled i visoke časti bila je česta tema umjetnika. Na priču o Josipu očito se odnosi i lik krave ili vola izvedene u reljefu u gornjem dijelu predmeta jer je Josip objasnio faraonu san o sedam debelih i sedam mršavih krava. ${ }^{27}$

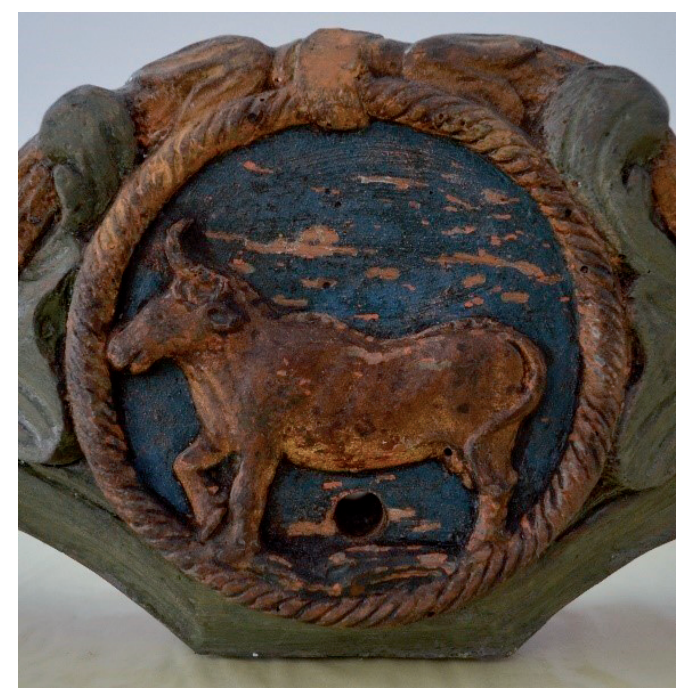

Slika 14. Reljefni prikaz krave na šaragi

Pregledom nekoliko primjeraka kočija kasnog 18. stoljeća, odnosno njihovih stražnjih stranica i njihovom usporedbom sa našom šaragom kao pomoć u eventualnom pokušaju rekonstrukcije kočije čiji je sastavni dio bila nađeno je nekoliko usporedivih primjeraka.

27 Stari zavjet, Knjiga postanka, Povijest Josipa i njegove braće (41:11:36). 
Radovi Zavoda za znanstveni rad HAZU Varaždin; br. 30, 2019, str. 327-348

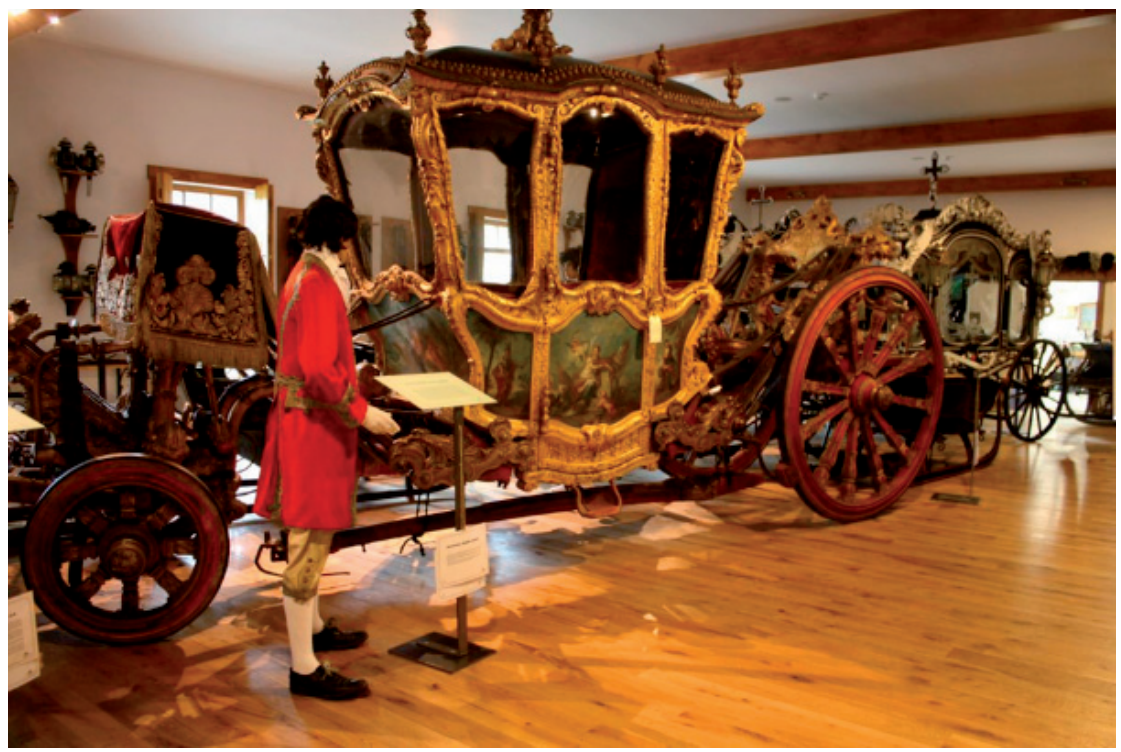

Slika 15. Stalni postav Muzeja kočija u Lisabonu

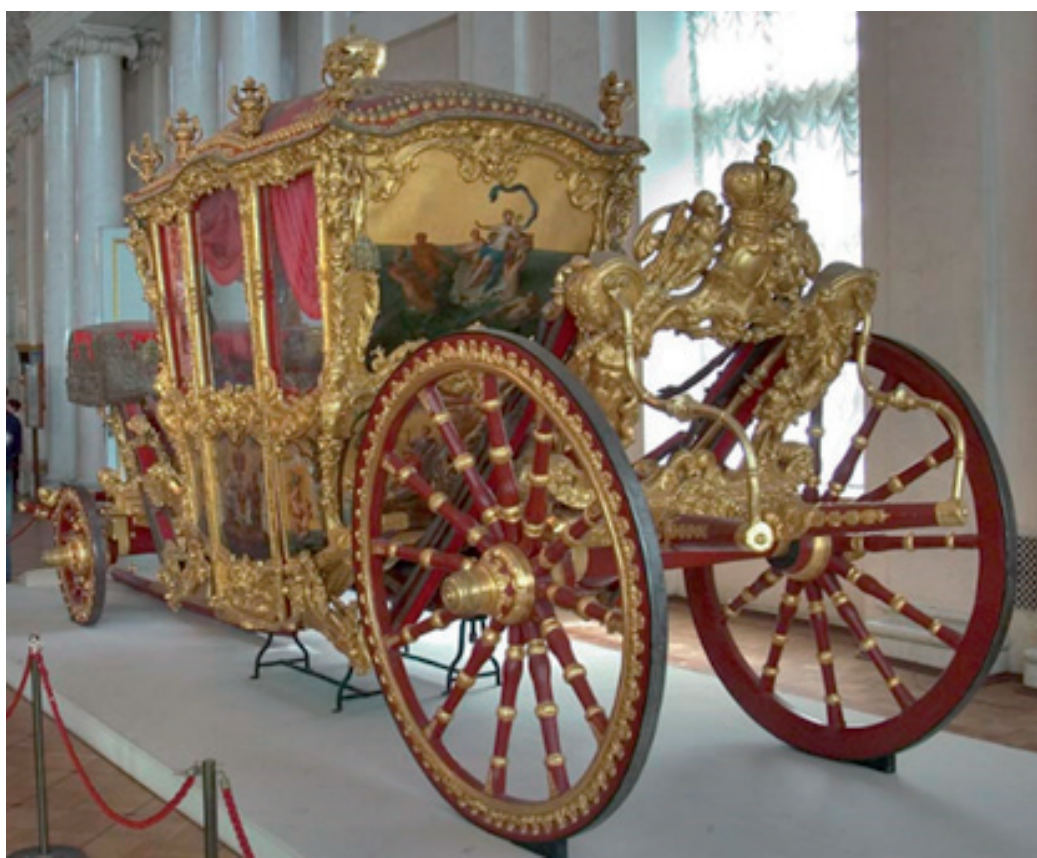

Slika 16. primjerak kočije 


\section{KONZERVATORSKO - RESTAURATORSKA ISTRAŽIVANJA NA ŠARAGI}

Šaraga je 27. veljače 2015. godine uz suglasnost nadležnog Konzervatorskog odjela u Varaždinu preuzeta iz Gradskog muzeja Varaždin, te je dopremljena u depo Hrvatskog restauratorskog zavoda, Restauratorskog odjela u Ludbregu. Kako bi predmet oslobodili ksilofagnih organizama, prije ulaska u radionice, 15. lipnja 2015. godine šaraga ulazi u komoru za dezinsekciju inertnim plinom dušikom. U hermetički zatvorenu komoru kompresijom se uvodi plin dušik pa se smanjenjem udjela kisika stvara atmosfera koja ne podržava život aerobnih organizama. Proces dezinsekcije trajao je deset tjedana i uspješno je završen.

Šaraga je zaprimljena iz GM Varaždin, gdje je bila pohranjena u čuvaonici u prizemlju tvrđave Stari grad Varaždin. ${ }^{28}$ Nakon ulaska u radionicu metodom opservacije ustanovljeno je da su prednja i stražnja strana šarage bile prekrivene slojem prljavštine i prašine. Čuvaonica u prizemlju tvrđave Stari grad nema regulaciju temperature i relativne vlage u prostoru, na šaragi nije bilo iskrivljenosti drveta, međutim ustanovljeno je da su sastavni dijelovi drvenog nosioca od kojih se sastoji umjetnina razdvojeni. Horizontalne drvene ploče od kojih je sastavljena središnja površina medaljona šarage su odvojene. Vidljiva su oštećenja od crvotočine na cijeloj površini drvenog nosioca. Na rezbarenom okviru koji okružuje središnju površinu šarage drveni nosilac je pretrpio manja mehanička oštećenja, a na krajnjem desnom dijelu gornje grede rezbarenog okvira nedostaje dio $u$ drvu rezbarenog lovorovog lista. Zbog odvajanja ploča nastale su pukotine na prizoru koji je naslikan na središnjoj površini i medaljonu šarage. Središnja površina koja se sastoji od horizontalnih dasaka pribijena je industrijskim čavlima za prečke na poleđini. Rezbareni okvir koji uokviruje medaljon također je pribijen industrijskim čavlima za središnju ploču. Vidljive su pukotine i rupe od čavala duž cijele središnje površine. Opservacijom zaključujemo da je okvir izrađen od hrastova drveta, a ploče na kojima je naslikan medaljon od drva jasena. Ploče na kojima je naslikan medaljon dobivene su kalanjem jasenovog trupca. Kalani dijelovi trupca piljeni su u blistače, a površina blistača je izravnana struganjem. Okvir koji okružuje ploče na koje je naslikan medaljon je rezbaren u hrastovu drvetu. Svi dijelovi šarage spojeni su drvenim tiplama. Vizualnom opservacijom na šaragi nismo pronašli nikakve oznake ili potpise.

Osnova i slikani sloj čvrsto prianjaju uz nosilac na svim oslikanim dijelovima šarage i ne postoji veća raspucanost. Završni lak je žute boje, a refleks površine je mat.

28 Šetalište Josipa Jurja Strossmayera 1, 42000, Varaždin. 
Zatečeni slojevi osnove, slikanog sloja i završnog laka su u dobrom stanju. Najveća oštećenja primjećuju se na nosiocu.

Šaraga je tijekom svoje povijesti bila obnavljana. Nepoznato je kada je postupak obnove bio izveden, ali je zbog upotrebe industrijskih čavala možemo smjestiti u prvu polovicu 20. st. ${ }^{29}$

Nakon opservacije izvedena su minimalna sondiranja slikanog sloja s ciljem utvrđivanja stanja, tehnika, kvalitete i sačuvanosti stratigrafijskih slojeva polikromije na svim dijelovima umjetnine. Izrađene su kemijske probe uklanjanja sloja prljavštine, laka i repolikromije. Uzeti su uzorci radi njihove kvalitativne laboratorijske analize u svrhu identifikacije korištenih pigmenata i veziva u slikanom sloju. Uzorak je uzet sa okvira koji okružuje središnju oslikanu površinu, te sa pozlaćenog lista lovora na okviru. Na središnjoj oslikanoj površini uzeti su uzorci sa kartuše ispod medaljona, te sa pozlaćene trake oko medaljona.

Nakon provedenih konzervatorsko-restauratorskih istraživanja možemo zaključiti da je izgled šarage prije restauratorskih radova ponajviše odredila obnova koja je bila izvedena u 20 st. industrijskim čavlima. Obnova je uzrokovala razdvajanje sastavnih dijelova drvenog nosioca od kojeg je građena umjetnina.

Osnova je u izvornom sloju uljeno-tutkalno-kredna te prianja čvrsto uz nosilac i u dobrom je stanju. Na središnjoj ploči postoji jedan sloj osnove koji je kistom nanesen do ruba ploče. Na rezbarenom okviru postoji jedan sloj osnove koji je nanesen kistom do ruba okvira. Također je primijećeno da na rezbarenim listovima lovora na kojima je polimentna pozlata nema izvornog sloja osnove. Osnova također nedostaje na mjestima gdje su kroz slikani sloj na licu slike zabijeni čavli. Slikani sloj je na svim oslikanim površinama šarage nanesen kistom i prianja čvrsto uz osnovu. Na cijeloj površini šarage slikani slojevi su u dobrom stanju i nema veće raspucanosti.

Vezivo izvornog slikanog sloja na svim dijelovima šarage je tempera. Primijećeno je da izvorni slikani sloj nedostaje u medaljonu, na gornjoj polovici slike koji prikazuje nebo. Slikani sloj je na tom mjestu istanjen do osnove ili nedostaje u potpunosti. Na mjestu gdje nedostaje slikani sloj, zatečena je repolikromija koja je nastala u nepoznato vrijeme.

Rezbareni listovi lovora i akantusa na okviru koji okružuje središnju oslikanu površinu pozlaćeni su polimentnom pozlatom. Središnja oslikana površina je u cijelosti lakirana lakom koji je potamnio i narušio vizualnu percepciju slike u medaljonu.

29 Prema dostupnoj muzejskoj dokumentaciji za vrijeme boravka predmeta u Muzeju na njemu nisu obavljane konzervatorsko-restauratorske intervencije. 
Boja završnog laka je žuta, a refleks površine je mat. Lak je nanesen kistom u tankom sloju. Topljivost laka je teška.

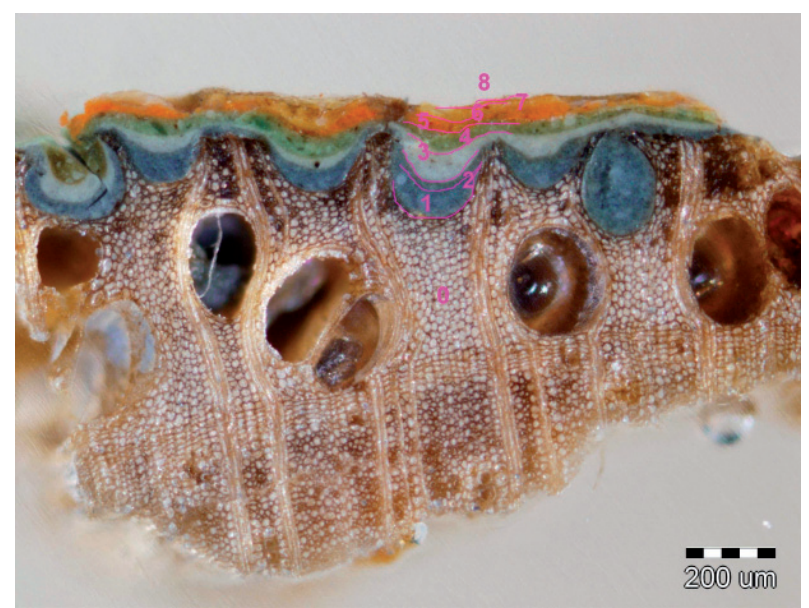

Slika 17. Mikrofotografija poprečnog presjeka uzorka broj 20020.

(Arhiva HRZ RC Ludbreg, 2016.)

Na temelju uzoraka polikromije laboratorijske analize u svrhu identifikacije korištenih pigmenata i veziva u slikanom sloju uzorka 20020 na pozlaćenom akantusu okvira šarage pokazale su slijedeće pigmente kronološkim redom:

1. Azurit, ${ }^{30}$ 2. malahit, ${ }^{31}$ 3. olovna bijela i malahit, 4. malahit, 5. minij, željezni oksid, 6. olovno - kositrena žuta, željezni oksid, 7. zlato, 8. organski premaz.

$\mathrm{Na}$ temelju analiza možemo zaključiti da na mjestu gdje je uzet uzorak 20020 na kojem se danas nalazi polimentna pozlata izvorno pozlate nije bilo, već je akantus oslikan pigmentom azuritom izravno na nosilac bez osnove. Također se može zaključiti da je akantus repolikromiran nekoliko puta, a posljednji sloj je polimentna pozlata koju vidimo i danas. Šaraga je preko cijele površine premazana tankim slojem nepoznatog laka; organskim premazom, koji je potamnio. Rezultati analiza upućuju da je proteinsko vezivo korišteno u sloju izvornog oslika i u svim slojevima repolikromije.

Dana 4. studenog 2016. godine sastala se komisija s predstavnicima Gradskog muzeja Varaždin, Hrvatskog restauratorskog zavoda i nadležnog Konzervatorskog odjela u Varaždinu. Komisija je na temelju konzervatorsko-restauratorskih istra-

30 R. D. HARLEY, Artists Pigments c. 1600-1835, str. 46.

31 Isto, str. 79. 
živanja obavljenih u Hrvatskom restauratorskom zavodu zaključila da je šaragu neophodno rastaviti na sastavne dijelove i ukloniti sve industrijske čavle koji su zabijeni za vrijeme prijašnje nestručne obnove.

\section{Konzervatorsko - restauratorski zahvati na šaragi}

Nakon pripremnih radova šaraga je rastavljena na sastavne dijelove. Razdvajanje umjetnine je izvedeno stručno, bez dodatnih trauma za nosilac šarage.
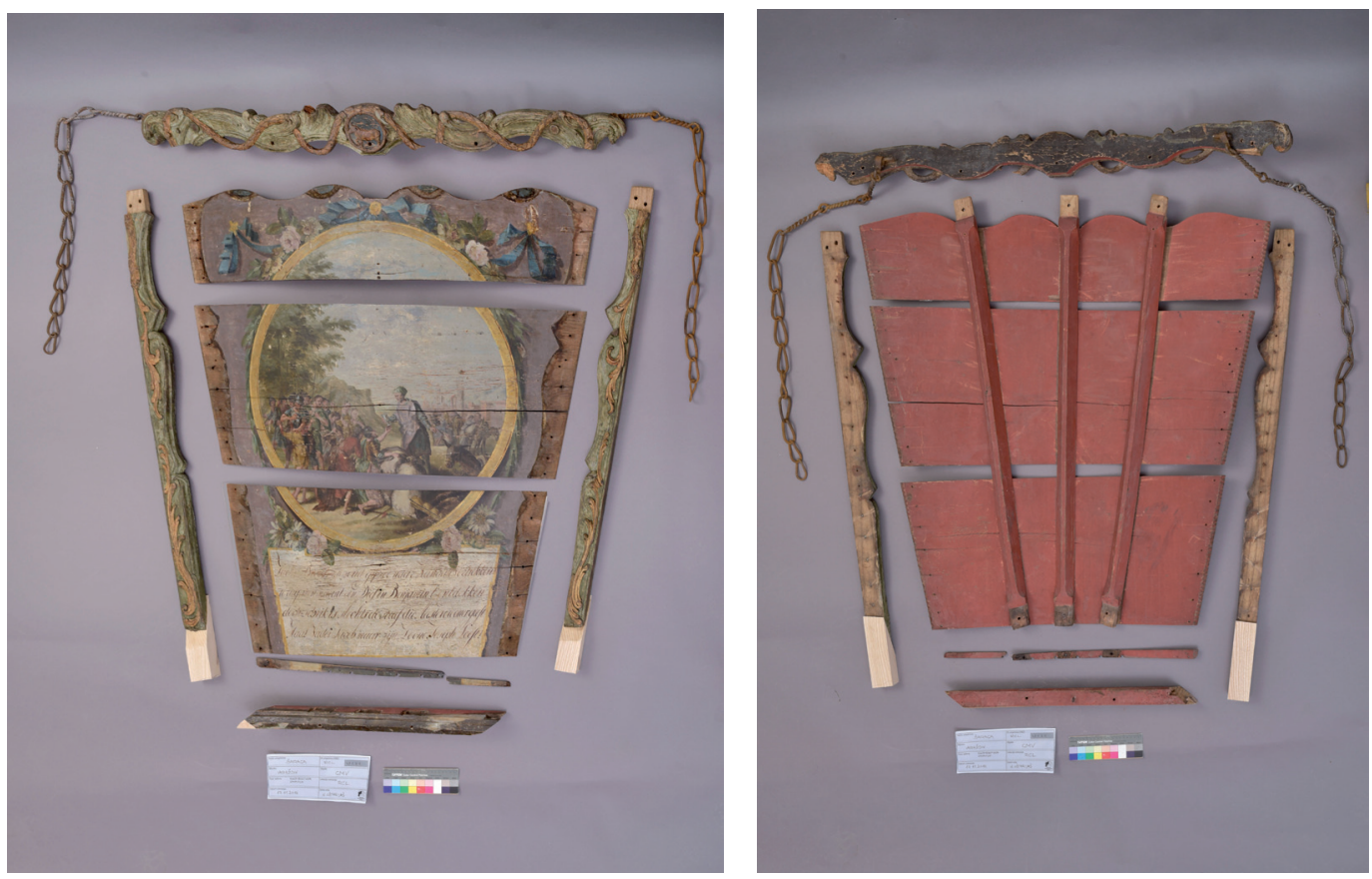

Slika 18. Prednja i stražnja strana šarage nakon razdvajanja na sastavne dijelove (Arhiva HRZ RC Ludbreg, 2016.)

Nakon razdvajanja predmeta na sastavne dijelova, na prečkama sa poleđine pronađena je štavljena koža koja amortizira vibracije prilikom vožnje kočije. Utvrđeno je da je korišten velik broj drvenih tipli koje konstrukciju šarage čine izrazito čvrstom i izdržljivom. Uklonjen je velik broj industrijskih čavala koji su zabijeni u šaragu za vrijeme obnove u 20. st. 


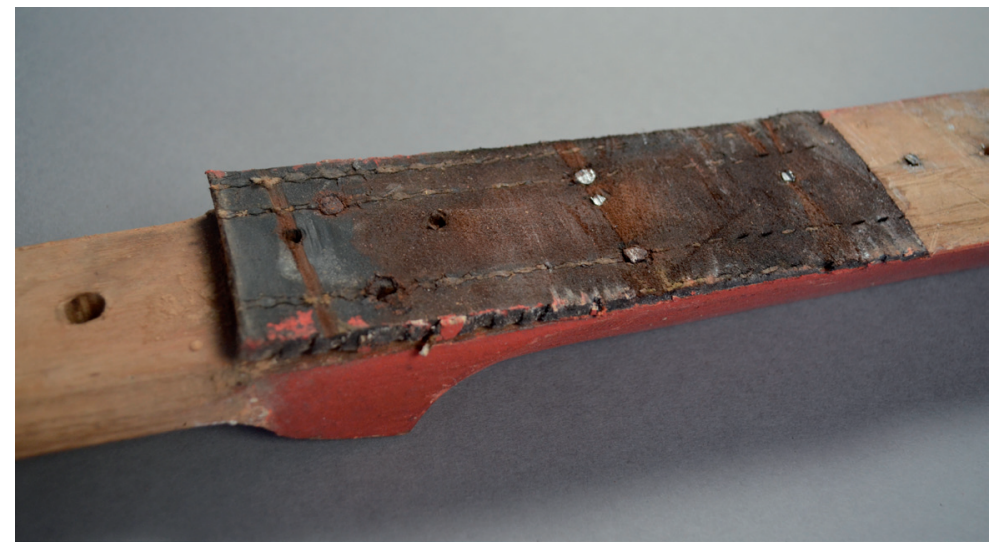

Slika 19. Štavljena koža na prečkama s pozadine šarage nakon razdvajanja na sastavne dijelove (Arhiva HRZ RC Ludbreg, 2016.)

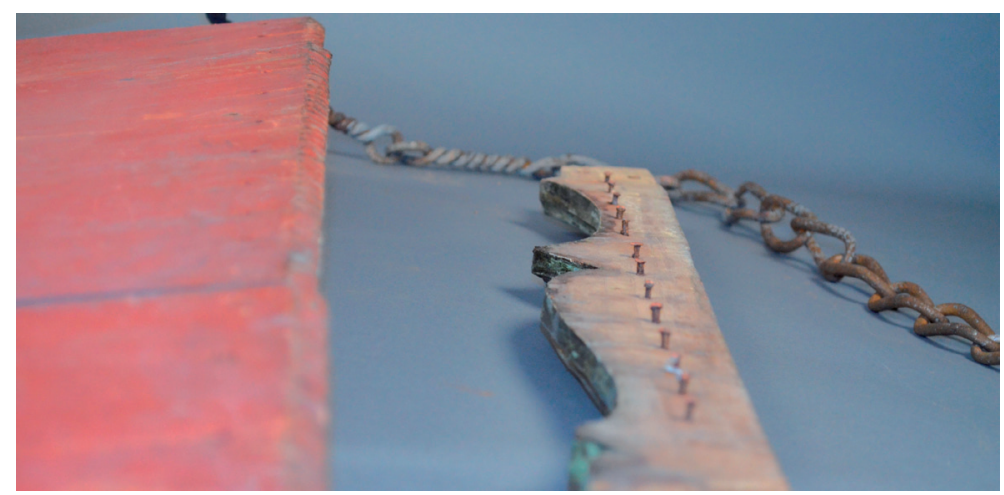

Slika 20. Industrijski čavli na pozadini rezbarenog okvira šarage nakon razdvajanja na sastavne dijelove (Arhiva HRZ RC Ludbreg, 2016.)

Kako je analizama ustanovljeno stanje drvenog nosioca, osnove i slikanog sloja, pristupilo se konzervatorsko-restauratorskom postupku uklanjanja potamnjelog organskog premaza i prljavštine s lica. Uklanjanje je izvedeno kemijskim putem acetonom, a nakon toga izvedeno je dočišćavanje 5\%-tnom amonijačnom vodom. Na svim oštećenim dijelovima osnove slikanog sloja nanesena je nova osnova dobivena miješanjem šampanjske i bolonjske krede u omjeru 1:1 u $8 \%$-noj otopini kožnog tutkala u destiliranoj vodi. Nova kredno-tutkalna osnova nivelirana je s okolnim izvorno sačuvanim slikanim slojem te je izolirana 5\%-tnim šelakom u etanolu. Nanesen je prvi sloj boje tzv. podslik (akvarelne boje Winsor \& Newton) kojim su izvedena nužna toniranja novih dijelova osnove. 
Retuš je izveden na šelakom izolirane kredne nadoknade osnove. Završni retuš izveden je tehnikom totalnog retuša pigmentima u prahu (Krämer) u Gummi arabici i lazurnim restauratorskim bojama „Restauro" s malo terpentina i damara (omjer 1:8). Završno lakiranje radi zaštite slikanog sloja izvedeno je $4 \%$-tnim damar lakom u terpentinskom ulju.

\section{Monitoring i montaža dijelova šarage u cjelinu}

Kako su najveća oštećenja šarage postojala na drvenom nosiocu koji je doživio mehanička oštećenja industrijskim čavlima, posebna se pozornost posvetila konzervatorsko-restauratorskim zahvatima na nosiocu. Cilj konzervatorsko-restauratorskog zahvata je zaustavljanje procesa koji oštećuju umjetninu i vraćanje nosioca na izvornu poziciju.

Središnje ploče šarage na kojima su naslikani medaljon i kartuša s natpisom, stegnute su na izvornu poziciju pomoćnom drvenom stegom. Izvršio se monitoring ploča stegnutih na izvornu poziciju. Problem razdvajanja ploča riješen je montiranjem rezbarenog okvira na ploče pokretnim mjedenim čavlićima koji omogućavaju prirodno kretanje drveta bez stvaranja sila koje mogu oštetiti nosilac.

Konzervatorsko-restauratorski radovi izvršeni su u prostorijama Restauratorskog odjela Ludbreg, a sve faze radova su fotografski dokumentirane.

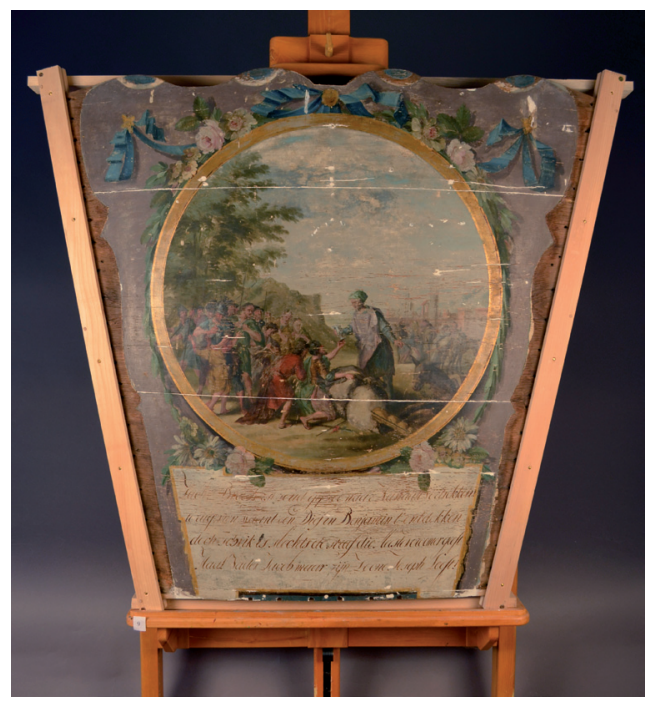

Slika 21. Šaraga stegnuta na izvornu poziciju pomoćnom drvenom stegom. (Arhiva HRZ RC Ludbreg, 2016.) 


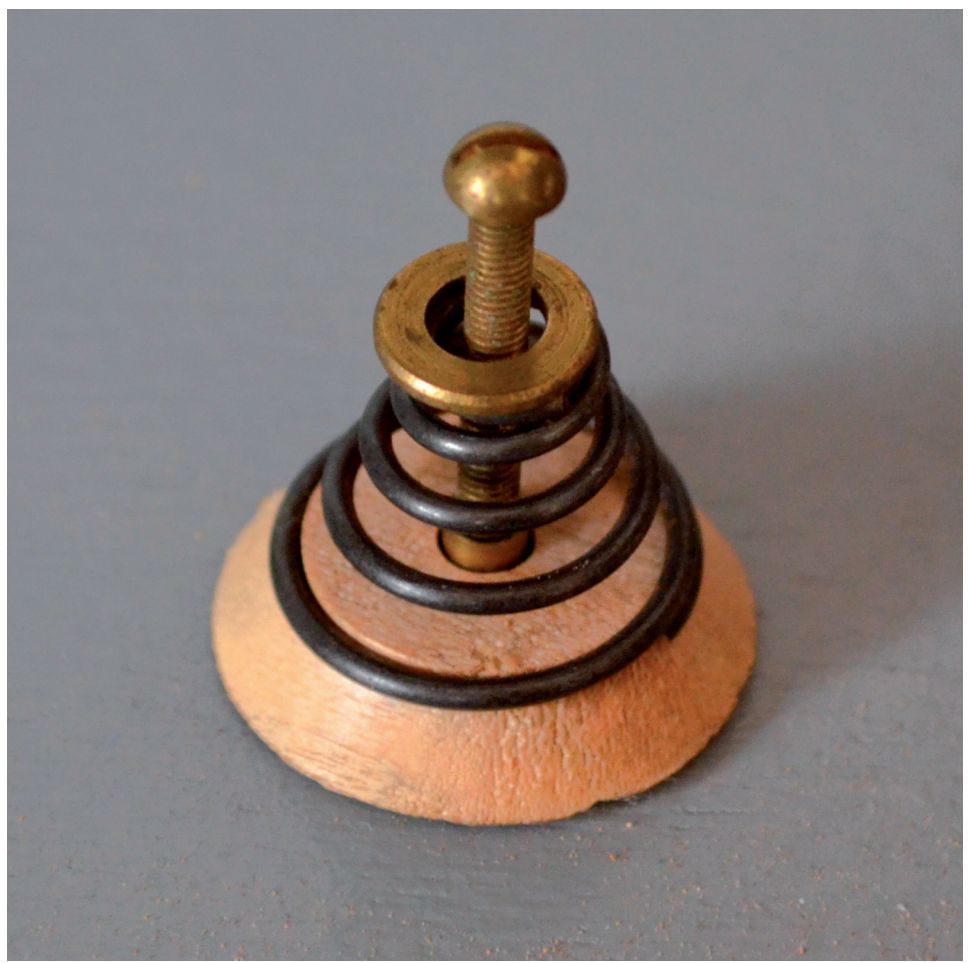

Slika 22. Pokretni mjedeni čavlić (Arhiva HRZ RC Ludbreg, 2016.)

\section{LITERATURA I IZVORI}

1/ R. D. HARLEY, Artists 'Pigments c. 1600-1835. Butterworth Scientific, London, 1982., 46, 79.

2/ Achim UNGER, A. P. SCHNIEWIND, Wibke UNGER, „Conservation of Wood Artifacts“, Springer-Verlag Berlin Heidelberg, 2001.

3/ Richard, WOLBERS, Cleaning Painted Surfaces, Aqueous Methods, second edition, London, Archetype Publications Ltd, 2003.

4/ Nicolaus, KNUT, The Restoration of Paintings, Germany, Konemann, 1999.

5/ Arhiva Restauratorskog odjela Hrvatskog restauratorskog zavoda u Ludbregu, Dokumentacija konzervatorsko-restauratorskih radova na šaragi iz Gradskog muzeja Varaždin u Varaždinu, DOS br. RCL 47.1.7., Ludbreg 2015.-2017. Arhiva Restauratorskog odjela Hrvatskog restauratorskog zavoda u Ludbregu, LABORATORIJSKO IZVJEŠĆE br. 219/2015.

6/ ANIĆ - KLAIĆ - DOMOVIĆ, Rječnik stranih riječi, Zagreb, 2002., 349, 1364. 
7/ Sanja CVETNIĆ, Ikonografija nakon Tridentskog sabora i hrvatska likovna baština, Sveučilište u Zagrebu, Filozofski fakultet, Zagreb, 2007.

8/ James HALL, Rječnik tema i simbola u umjetnosti, Zagreb, 1991., 143. -144.

9/ Branko SVOBODA, Stare vinogradske kurije i klijeti Zapisi o starim goričnim kurijama i klijetima na Varaždinbregu, Zagreb, 1967.

10/ Magdalena LONČARIĆ, Židovska zajednica u Varaždinu, Varaždin, 2017., 178. $-187$.

11/ Arhivska građa u Državnom arhivu u Varaždinu, 1112 OBITELJ LEITNER-PUSTZ, VARAŽDIN, JALKOVEC, 1868-1955., 6 KUTIJA.

12/ Arhiv Gradskog muzeja Varaždin, obitelj Leitner.

Citiranje s Interneta

1/ Podaci s interneta o Nacionalnom muzeju kočija (Museu Nacional dos Coches) u Lisabonu, Portugal, https://www.lisbon.net/national-coach-museum, (05.06.2019).

2/ https://www.scribd.com/doc/123120058/ARHAIZMI-ISTO\%C4\%8CNE-SLAVONIJE, (05. 06. 2019.).

\section{SAŽETAK}

\section{ŠARAGA IZ DVORCA OBITELJI LEITNER U JALKOVCU}

Tekst je sastavljen od dva dijela: prvi analizira predmet u muzejskoj zbirci Kulturno-povijesnog odjela GMV i daje pregled njegovih prvotnih vlasnika, članova varaždinske obitelji Leitner. Drugi dio opisuje opsežne i složene konzervatorsko-restauratorske radove koje provode stručnjaci Restauratorskog odjela Ludbreg HRZ-a u Zagrebu.

U muzejskoj zbirci Gradskog muzeja Varaždin zatečen je zanimljiv, ali jako oštećen predmet o kojem nije bilo saznanja o čemu govori podatak da nije bio niti inventiran. Istraživanjem je utvrđeno da je riječ o vrijednom umjetničkom i kulturološkom predmetu, oslikanom dijelu kočije iz vlasništva varaždinske obitelji Leitner. Zahvaljujući tome predmet je uvršten u program zaštite.

U Restauratorskom centru Hrvatskog restauratorskog zavoda u Ludbregu od 2015. do 2016. godine na šaragi su provedeni konzervatorsko-restauratorski radovi. Tijekom tih radova otkriven je izvorni oslik šarage te stratigrafija slikanih slojeva repolikromije. Otkriveni su razlozi odvajanja drvenih površina od kojih se sastoji središnja oslikana ploča. Industrijski čavli koji su uzrokovali odvajanje 
dasaka su uklonjeni, a završna montaža je izvedena pokretnim mjedenim čavlićima koji će spriječiti moguća oštećenja.

Ključne riječi: Jalkovec; obitelj Leitner; kočija, šaraga; starozavjetna priča o Josipu; mikrofotografija; stratigrafija; štavljena koža; retuš Gummi arabicom; pokretni mjedeni čavlić.

\section{SUMMARY \\ PAINTED REAR PANEL OF A CARRIAGE, ŠARAGA, FROM THE LEITNER CASTLE IN JALKOVEC}

The text consists of two parts: the first one analysing the item called šaraga in the holdings of the Department of Culture and History of the Varaždin City Museum, and providing insight into its initial owners, members of the aristocratic family of Leitner, and the second one giving a comprehensive description of the complex restoration and conservation works conducted by the experts of the Restoration Department in Ludbreg within the Croatian Conservation Institute in Zagreb.

In the collection of the Varaždin City Museum, an interesting, but severely damaged object was found, on which no museum records were detected. The research confirmed that the item was of significant artistic and cultural value and that it represented a part of a carriage in the former ownership of the Leitner family from Varaždin. Owing to the data collected and the evaluation of the item, it was enlisted in the conservation program of the Croatian Conservation Institute.

In the Restoration Department in Ludbreg, in the period from 2015 to 2016, conservation and restoration work was performed on the item, during which original painting and paint stratigraphy were discovered. The cause of separation of the boards comprising the central painted panel was disovered. Industrial nails causing the separation were removed, and will be replaced with flexible brass nails, hence preventing future damage. Upon finishing the restoration work, the item will be included into the permanent exhibition of the Department of Culture and History in the Old Town.

Key Words: Jalkovec; Leitner family; carriage; šaraga; Old Testament story of Joseph; microphotography; stratigraphy; tanned leather; retouching with Gum arabic; movable brass nail. 